Volume 29

$1-1-1991$

\title{
The Uncertain Promise of Law: Lessons from Bhopal
}

Jamie Cassels

Follow this and additional works at: https://digitalcommons.osgoode.yorku.ca/ohlj

Part of the Torts Commons

Article

\section{(c) (1) (9)}

This work is licensed under a Creative Commons Attribution-Noncommercial-No Derivative Works 4.0 License.

\section{Citation Information}

Cassels, Jamie. "The Uncertain Promise of Law: Lessons from Bhopal." Osgoode Hall Law Journal 29.1 (1991) : 1-50.

https://digitalcommons.osgoode.yorku.ca/ohlj/vol29/iss1/1

This Article is brought to you for free and open access by the Journals at Osgoode Digital Commons. It has been accepted for inclusion in Osgoode Hall Law Journal by an authorized editor of Osgoode Digital Commons. 


\title{
The Uncertain Promise of Law: Lessons from Bhopal
}

\begin{abstract}
This paper describes the course of the litigation following the Bhopal disaster. It begins with a brief description of the various failures in risk assessment and management that gave rise to the hazardous conditions in Bhopal, and then describes in more detail the resulting legal proceedings. Specifying a number of modest criteria against which the success of the litigation can be measured, the paper examines why traditional tort processes are unlikely to succeed in the case of mass hazards. The paper describes and analyzes a number of significant reforms forged by the Indian courts in response to the Bhopal disaster, and seeks to articulate some of the lessons to be learned from these efforts.
\end{abstract}

\section{Keywords}

Mass torts; Bhopal Union Carbide Plant Disaster; Bhopal; India; 1984

\section{Creative Commons License}

\section{(c) (i) (2)}

This work is licensed under a Creative Commons Attribution-Noncommercial-No Derivative Works 4.0 License. 


\title{
THE UNCERTAIN PROMISE OF LAW: LESSONS FROM BHOPAL
}

\author{
By JAMIE CASSELS ${ }^{*}$
}

This paper describes the course of the litigation following the Bhopal disaster. It begins with a brief description of the various failures in risk assessment and management that gave rise to the hazardous conditions in Bhopal, and then describes in more detail the resulting legal proceedings. Specifying a number of modest criteria against which the success of the litigation can be measured, the paper examines why traditional tort processes are unlikely to succeed in the case of mass hazards. The paper describes and analyzes a number of significant reforms forged by the Indian courts in response to the Bhopal disaster, and seeks to articulate some of the lessons to be learned from these efforts.

I. INTRODUCTION $\ldots \ldots \ldots \ldots \ldots \ldots \ldots \ldots \ldots \ldots \ldots \ldots \ldots \ldots \ldots \ldots$

II. ANATOMY OF A DISASTER $\ldots \ldots \ldots \ldots \ldots \ldots \ldots \ldots \ldots \ldots$

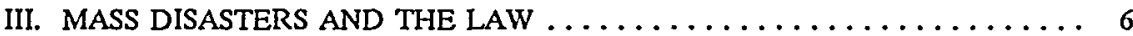

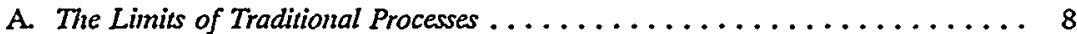

B. Legalizing a Disaster: The Initial Skimishing . . . . . . . . . . . 10

IV. DEVISING A PROCESS AND FINDING A FORUM . . . . . . . . . . 12

A. The Bhopal Gas Leak Disaster Act . . . . . . . . . . . . . . . 12

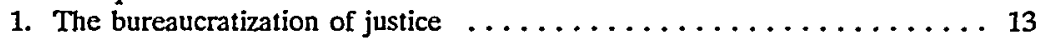

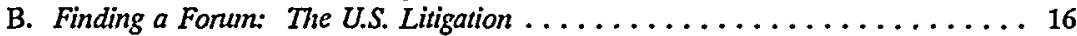

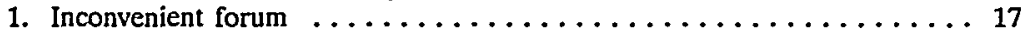

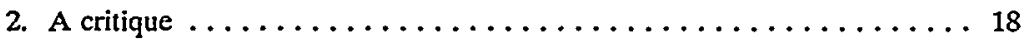

V. THE LITIGATION IN INDIA . . . . . . . . . . . . . . . . 20

A. Substantive Concems: Proof of Liability and the Standard of Care . . . . . . 23

1. Shriram fertilizers ....................... 25

B. Allocating Responsibility: MNCs and the Corporate Veil ........... 26

1. Water down the Ganges . . . . . . . . . . . . . . . . 28

○

Copyright, 1991, Jamie Cassels.

* Associate Professor, University of Victoria, Faculty of Law. The author would like to thank the SSHRC for research support in preparing this paper, and the Indian Law Institute for the use of their research facilities. 
C. And In the Meantime, What of the Victims? ............... 31

1. The revenge of the colonies $\ldots \ldots \ldots \ldots \ldots \ldots \ldots \ldots \ldots \ldots \ldots \ldots \ldots$

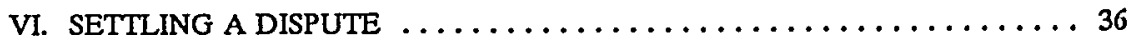

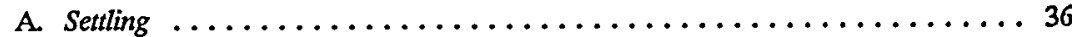

B. Unsettling ............................ 42

VII. CONCLUSION $\ldots \ldots \ldots \ldots \ldots \ldots \ldots \ldots \ldots \ldots \ldots \ldots \ldots, 43$

\section{INTRODUCTION}

Almost six years have passed since a massive discharge of lethal gas from the Union Carbide factory in Bhopal India killed over twenty-five hundred people, either as they slept or as they fled in terror during the night. Hundreds more have since died and many thousands remain injured or affected to this day. With the possible exception of Chernobyl, the Bhopal disaster was the worst single-incident industrial catastrophe in history.

This paper describes the course of the Bhopal litigation. It examines the promises made by law to the victims of hazardous technology and "social progress" and attempts to gauge the ability of the legal process to keep those promises. The paper is concerned primarily with the question of how to repair the damage resulting from mass exposure torts, leaving aside for the time being the more important question of how to avoid such incidents in the first place. I first describe the challenges presented by a disaster of such proportions and suggest a number of relatively modest criteria against which the legal response can be measured. I then describe some of the unique developments in the Bhopal litigation itself. These include the consolidation of the claims by the Indian government; the attempt to bring the action in the courts of the United States; the formulation of a principle of absolute liability for industrial hazards; the effort to develop a scheme for interim compensation for the victims; and finally, the suggestion of a theory of enterprise liability by which a multinational corporation might be liable for the defaults of its subsidiaries. The paper concludes with a brief account of recent developments, including the efforts by the Indian Supreme Court to bring the legal tragedy to a close. 
Within the limits of a short paper, I seek to highlight the problems posed by a catastrophe of such magnitude, to analyze the success of the legal response, and to indicate what can be learned from the tragedy. I should admit that this narrative is couched in the context of considerable scepticism about the ability of both traditional litigative responses and the private law of tort to play a serious role in preventing such a tragedy, or to repair the human consequences once the tragedy has occurred. One might object, therefore, that because of the disaster's magnitude, and its unique political, economic, and cultural context, the Bhopal case too easily illustrates a preconceived conclusion. What I hope to demonstrate is that while the Bhopal case may be a vivid illustration of the problem, it is neither unique nor peculiar. And while the Bhopal disaster must be understood in the context of the relationship between multinationals and developing countries it cannot be confined to that context. Indeed, a foreign observer cannot help but be impressed by the dynamism of Indian law, and occasionally excited by its promises. Yet in the end, the Bhopal story is one about the limitations of law; and while the Indian legal system differs in important ways from our own, this story holds important lessons for us all.

\section{ANATOMY OF A DISASTER}

The Bhopal facility was operated by Union Carbide of India Ltd (UCIL). The project was initiated in 1969 through negotiations between the Union Carbide Corporation (UCC), headquartered in the United States, and the Union of India (UOI). UCC owned 50.9 per cent of UCIL and Indian government financial institutions owned approximately 20 per cent. The plant manufactured pesticides and insecticides containing methyl-isocyanate (MIC). In 1980 the plant began manufacturing the MIC itself. This chemical is known to be very dangerous - it is extremely volatile and highly toxic. Its effects on human beings are horribly diverse and include lung damage, blindness, emphysema, tuberculosis, spleen and liver damage, nervous and psychological disorders, gynaecological damage, and birth defects. On the night of 2 December 1984, a chemical reaction ruptured the MIC storage tank and spewed an estimated 
forty-five tons of toxic gas across the city, causing a catastrophe affecting the lives of five hundred thousand people.

The immediate cause of the disaster was probably the seepage of water into the MIC storage tank causing an exothermic chemical reaction. Union Carbide initially claimed the catastrophe was the result of sabotage - blame was first laid on Sikh extremists and then on a disgruntled employee. Little evidence was ever offered to support these allegations; but Union Carbide scientists claimed that accidental introduction of water into the MIC tank was technically impossible and Union Carbide consistently maintained the sabotage theory in anticipation of litigation. The company later claimed to have both a witness to support its theory and a "likely candidate" for the role of saboteur. The more widely accepted explanation of the cause of the accident was human and technical failure during a routine cleaning operation. A failure to maintain and close a series of valves while flushing the system resulted in the overflow of water into the storage tank. I $^{\text {I }}$

Whether or not the precise details of this scenario are correct, one thing is certain: the facility at Bhopal was a disaster waiting to happen. While Union Carbide characterized the incident as the result of "a unique combination of unusual events," ${ }^{2}$ the danger signs were there for all to see. When Union Carbide and the government of India decided to manufacture and store large quantities of MIC, they failed to assess the risk of locating such a hazardous technology within an underdeveloped infrastructure. As the risks became more apparent they failed to respond to them. Indeed, a local journalist had been warning of the impending

1 This is the conclusion reached by most of the authors who have examined the causes of the Bhopal disaster. For full accounts of the causes of the disaster see: A. Bhargava, "The Bhopal Incident and Union Carbide: Ramifications of an Industrial Accident" (1986) 18:4 Bulletin of Concerned Asian Scholars 2; A De Grazia, A Cloud Over Bhopal: Causes, Consequences, and Constructive Solutions (Bombay: Kalos Foundation, 1985); L. Everest, Behind the Poison Cloud: Union Carbide's Bhopal Massacre (Chicago: Banner Press, 1986); S. Hazarika, Bhopal: The Lessons of a Tragedy (New Delhi: Penguin Books, 1987); P. Shrivastava, Managing Industrial Crises: Lessons of Bhopal (New Delhi: Vision Books, 1987); D. Weir, The Bhopal Syndrome: Pesticides, Environment, and Health (San Francisco: Sierra Club Books, 1987).

2 Union Carbide Corporation, Bhopal Methyl Isocyanate Incident Investigation Team Report, March 1985, cited in Everest, supra, note 1 at 17-18. 
disaster for two years. ${ }^{3}$ There had already been a series of leaks at the plant killing one worker and injuring dozens of others, ${ }^{4}$ and Union Carbide's own reports acknowledged a serious risk of a further incident. $^{5}$ No action was taken in response to these warnings.

The absence of both risk assessment and hazard communication was compounded by a series of operational and technical failures. The Bhopal facility had been losing money for years. Skilled employees had left, training and morale had deteriorated, and operating procedures had become slipshod. The plant was poorly maintained and the safety equipment - including pressure gauges, cooling systems, flare towers, gas scrubbers, and water sprayers was either inadequate or inoperative on the night of the disaster. Ironically, in the months immediately preceding the disaster, Union Carbide had been considering ways to divest itself of the Indian operation.

The magnitude of the disaster was exacerbated by an absence of planning. The plant was located close to a densely populated area of the city. There was no information in the community about the nature of the substances at the plant or the technological and environmental risks. Nor were there effective warning or emergency procedures in place, either within the plant or within the community. The medical facilities were, of course, completely unprepared for the disaster, and, despite valiant efforts, doctors were seriously hampered by their lack of knowledge about the nature of the gas and the appropriate treatment.

Nor was the legal system capable of managing the risk at Bhopal. As in many developing nations, Indian health and safety

3 R. Keswani, "Bhopal Sitting on Top of a Volcano" and "Bhopal on the Brink of a Disaster," referred to in affidavit of Rajkumar Keswani, in the Supreme Court of India, in Rajkumar Keswani v. Union of India, writ petition no. 281 of 1989 (available from the author).

4 On 24 December 1981, one worker had died and three others were hospitalized following the leak of phosgene. On 9 February 1982, twenty-five workers were hospitalized following another leak. Reported in Union of India Memorandum, reproduced in U. Baxi \& T. Paul, eds, Mass Disasters and Multinational Liability: The Bhopal Case (Bombay: N.M. Tripathi, 1986) at 72.

5 Reported in Union of India Memorandum, reproduced in Baxi \& T. Paul, ibid. at 73. 
regulations are underdeveloped and underenforced. ${ }^{6}$ Departments are poorly funded, understaffed, and unable to manage or control the environmental risks of the multitude of hazardous industries in the country. International law does not fill the safety gap in developing countries. The "soft" regulations for multinational business and technology transfers, promulgated by international organizations, consist of voluntary codes of conduct and non-binding guidelines. These regulations do not reach the actual operations of industry in developing countries. ${ }^{7}$ In the name of free trade and in respect for national sovereignty, the regulation of industry is left to the host state.

Thus the Bhopal plant had been effectively orphaned by its parent corporation and left virtually unregulated by Indian or international law. What happened in Bhopal was not a freak combination of unexpected events, but a systematic series of failures: at the planning stage; on the technological level; in the management and operational practices; and, finally, in the social and legal infrastructure within which the hazardous technology was located.

\section{MASS DISASTERS AND THE LAW}

Most lawyers would probably agree that there are two overriding goals to achieve in designing a process to repair the damage done in Bhopal. The first goal is to compensate the victims, and the second is to reduce the risk of such occurrences in the future. These two goals are limited by several considerations; but the most important is that the solution to the problem should not itself create further damage or impose unnecessary social costs.

6 See T. Gladwin, "A Case Study of the Bhopal Tragedy" in C.S. Pearson ed., Multinational Corporations, Environment, and the Third World (Durham, NC: Duke University Press, 1987) 3; C.M. Abraham \& A. Rosencranz, "An Evaluation of Pollution Control Legislation in India" (1986) 11 Colum. J. Envt'l L. 101; H.C. Dhalakia, "Air Pollution Control" in S.L. Agarwal, ed., Legal Control of Environmental Pollution (Bombay: N.M. Tripathi, 1977).

7 See R.E. Lutz, "The Export of Danger: A View From the Developed World" (1988) 20 N.Y.U. J. Int'l L. \& Pol. 629. 
To elaborate on these goals:

1. The process must, first and foremost, provide timely and adequate compensation to the victims. It makes the least sense to leave the victims, of all the parties involved, to bear the costs of the disaster. They are blameless. They are not direct beneficiaries of the operation and they are in no position to prevent the disaster.

2. The costs of a hazard must be placed upon the party who imposed those costs and benefitted from them, and, the damages should reflect the full social costs of the activity. This principle takes into account considerations of deterrence and, theoretically, provides a better basis for social cost accounting. It provides a safety incentive insofar as it forces economic actors to factor all social costs of production into their economic decisions.

3. There must be a provision for emergency and interim assistance given that final compensation will take time.

4. Processing of individual claims must begin at an early date. Otherwise, the complexity of the factual and medical evidence will make fact determination impossible.

5. The process must be accessible to the victims. Given the overwhelming poverty of the majority of the Bhopal victims, they cannot be left to pursue their claims individually. Some way to redress the massively uneven distribution of resources between individual victims and corporate tortfeasors must be found.

6. The structure for a solution must be cost efficient. It should maximize the value of the available compensation funds and minimize transactions costs - particularly, administrative and legal costs.

When stated as the goals of a compensation system, these criteria would be widely affirmed. However, when translated into concrete 
practices they are enormously controversial and complex, and may well be unattainable. The Bhopal story makes this abundantly clear.

\section{A. The Limits of Traditional Processes}

The Bhopal disaster is one more example of what are becoming known as mass disasters or mass exposure torts. Similar incidents have occurred in Seveso, Italy in 1976; Mexico City in 1984; Basel, Switzerland in 1986; and of course, at Chernobyl. The potential for such occurrences in Canada has been illustrated by incidents such as the Mississauga train derailment in 1979, the Lodgepole gas blow-out in $1982,{ }^{8}$ and the St. Basil Le Grand PCB warehouse fire in 1988.

Mass exposure problems are especially problematic for a number of reasons. In the first place, they typically involve complex technology, dangerous processes, and toxic materials. The factual matrix is thus enormously complicated. Difficult scientific, technical, and medical questions may be involved. The collection of data and proof of technical and medical theories is time consuming, controversial, and expensive. Even the question of what actually happened in Bhopal on the night of the disaster has not been settled and it probably never will be.

Secondly, medical causation is often difficult to establish, injuries may remain latent for years, and the long-term health effects of the incident may be unknown. The estimates of the number of injured and dead in Bhopal vary by tens of thousands, and the future medical consequences of the disaster can only be guessed. As many commentators argue, environmental accidents and toxic torts represent a new paradigm of "statistical causation" with which traditional notions of proof and responsibility are incapable of dealing. $\quad$ While the incidence of cancer, tuberculosis, asthma,

\footnotetext{
${ }^{8}$ See Alberta Energy Resources Conservation Board, Lodgepole Blowout Report - Causes, Effects, Actions (Calgary: Conservation Board, 1985).

${ }^{9}$ See, for example, R.H. Gaskins, Environmental Accidents: Personal Injury and Public Responsibility (Philadelphia: Temple University Press, 1989); D. Rosenberg, "The Causal Connection in Mass Exposure Cases: A 'Public Law' Vision of the Tort System" (1984) 97
} 
miscarriage, and birth defects may vastly increase after a toxic spill, there is no way of tracing individual cases to the spill. Doctors and medical researchers in Bhopal confirm that many of the MIC victims show no obvious unique physical symptoms which are distinguishable from the health problems that occur naturally in the city.

Thirdly, under the tort system a claimant must be able to trace causation back to the acts or omissions of a responsible party. But mass disasters such as Bhopal typically involve multiple actors interrelating through intricate chains of command and decision. Individualistic tort conceptions of legal responsibility and causation do not fit well when the incident is the result of a complex combination of individual, corporate, and governmental decisions, actions, and omissions. It will often be impossible to isolate responsibility by focusing on the individual actions or omissions of simply a few actors, and "blame" can easily be shifted from shoulder to shoulder ad infinitum.

The large number of victims and potential victims means that the litigation will be difficult to organize and enormously expensive. If tried on a case-by-case basis the process could last for years, involve a redundant and wasteful relitigation of similar issues, and generate legal fees into the hundreds of millions of dollars. In mass disasters the defendant can achieve economies of scale in the preparation of the lawsuit that are unavailable to the individual plaintiffs, thus tilting the tactical balance against the plaintiffs. When a multinational enterprise is involved, the situation is further complicated by transboundary issues of both a political and legal nature.

The potential liability of the defendant is often enormous and well beyond its insurance coverage. An adverse judgment may threaten the economic health of the defendant and there may be insufficient funds to meet the claims of the victims. Where the defendant is a thinly-capitalized affiliate of a larger company, as in the case of Bhopal, notions of limited liability and the corporate veil may preclude full recovery. The large potential damages award creates a strong incentive for the defendant to assume the most 
rigidly defensive posture in an effort to use all means to avoid, or at least postpone, a final finding of liability. Lengthy delays and enormous costs sap the power of victims to pursue their legal remedies in the traditional fashion.

\section{B. Legalizing a Disaster: The Initial Skirmishing}

The sheer magnitude of the disaster at Bhopal invited the main players to consider non-traditional approaches to its solution. The transnational nature of the dispute, its technical and legal complexity, the enormous number of potential parties, and the international public horror at what had happened all might have prompted the main players to seek some quick and adequate response to the disaster. One commentator, for example, suggested a bilateral agreement between India and the United States to establish a claims tribunal funded by India, the U.S., the Union Carbide Corporation (UCC), and Union Carbide of India Ltd. (UCIL). ${ }^{10}$ Others suggested the creation of special courts with expedited procedures. Few, if any, predicted that a traditional legal response would prove adequate to meet the needs of the case.

On the other hand, so-called non-traditional solutions to mass disasters, such as special compensation schemes, have been criticized in many quarters. The fear is that such models remove the burden of full compensation from industry. They risk undercompensating the victims, and, in the end, constitute a pact between industry and government amounting to little more than a licence to kill. $^{11}$ Special tribunals may become overly bureaucratic, and expedited procedures may require a significant relaxation of due process. This latter feature is particularly problematic in a transboundary case where any final judgment must be enforced in a foreign court which might object to the process adopted in the original jurisdiction. Rev. 835.

10 D.B. Magraw, "The Bhopal Disaster. Structuring a Solution" (1986) 57 U. Colo. L.

11 For a very effective argument along these lines, see P. Brodeur, Outragcous Misconduct: The Asbestos Industry on Trial (New York: Pantheon, 1985). 
Whatever the merits of the alternatives, a traditional legal response was precisely what the victims got. Both the government of India and Union Carbide immediately assumed defensive postures designed to control damage to their own position. Each sought to focus public attention away from their own potential responsibilities, to shift the locus of legal and moral blame to other parties, and to minimize their potential exposure. Compensation of the victims assumed a low priority against the political and economic imperatives of litigating liability.

Immediately following the disaster American lawyers flooded Bhopal. Within a week, hundreds of lawsuits had been filed in various courts in India and the United States. Victims were signed on, in some cases, at the rate of thousands per week - indicating that they were not giving or receiving much in the way of instructions or advice. ${ }^{12}$ While the involvement of American lawyers in the Bhopal case may have "broken the pattern of legal resignation ${ }^{13}$ in India, it probably also reduced the prospect of a quick, or non-traditional, solution. The problems were individualized and legalized. A hundred different lawyers presented themselves as authoritative spokespersons for the victims, a thousand legal strategies bloomed. Settlement negotiations were begun by one group and rejected by another. The hopes of the victims were raised impossibly high, while behind closed doors they were being used simply as bargaining chips by lawyers jockeying for control of the litigation. ${ }^{14}$

While the problems were in one sense "legalized" they were also politicized. Modern India has developed a vigorous tradition of social activism. In the case of Bhopal, this was manifested in the grassroots organizing of aid to the victims, the focusing of political pressure on government through media and organized protest, and the forming of medical and legal action groups to work for the

12 For an account of an American lawyer's involvement in Bhopal, see D.L. Rhode, "Solicitation" (1986) 36 J. Leg. Ed. 317.

13 M. Galanter, "When Legal Worlds Collide: Reflections on Bhopal, the Good Lawyer, and the American Law School" (1986) 36 J. Leg. Ed. 292 at 307 [hereinafter Legal Worlds].

14 See the account in J. Jenkins, The Litigators: The Powerful World of America's HighStakes Trial Lawyers (New York: Doubleday, 1989) at 67-120. 
victims. Most of the victims in Bhopal were poor daily wage labourers, unable to make their individual voices heard. Collective organization was thus needed to give them a say in their own fate. But while social action was undoubtedly essential to safeguard the interests of the victims, it also complicated the process further. With so many organizations guarding the victims' interests it became increasingly difficult to determine who spoke for whom.

\section{DEVISING A PROCESS AND FINDING A FORUM}

The most obvious problems in mass tort litigation arise simply because of the sheer number of people affected. At least thirty-five hundred people have now died from the gas leak and approximately forty thousand others remain seriously injured. In all, there are more than half a million claimants. Obviously, in a case of such proportions, traditional individualistic legal responses make little sense. The poverty of many victims would exclude them from any formal legal redress whatsoever. Even those who could afford to initiate legal proceedings would not last long against the legal artillery possessed by a multinational corporation. To litigate each case separately would be inefficient and so wasteful of public and private resources as to be absurd. The initial strategies of the parties legalized the disaster by presupposing litigation; however, the Indian government, recognizing the unparalleled nature of the problem, sought to devise a process to overcome the obvious limitations of individualized justice.

\section{A. The Bhopal Gas Leak Disaster Act}

A presidential ordinance, and later a statute, made the Indian government the exclusive representative of all the Bhopal victims. The Bhopal Gas Leak Disaster $A t^{15}$ applied retroactively but preserved the right of the victims to retain counsel and required that the government "have due regard to any matters which such

15 Bhopal Gas Leak Disaster (Processing of Claims) Ordinance, No. 1 of 1985; Bhopal Gas Leak Disaster (Processing of Claims) Act, No. 26 of 1985 (29 March 1985). 
persons may require to be urged with respect to [the] claim."16 The Act further authorized the establishment of a Claims Scheme as the primary mode of redress for the victims. It created a Commissioner whose function would be to administer the scheme - registering, recording, and processing individual claims.

This statute gave the Central Government parens patriae control over the Bhopal case. It purported all but to eliminate individual pursuit of claims and proposed to substitute an administrative framework for the disbursement of any compensation monies. Of more immediate importance, it allowed the Indian government to take over the litigation already commenced in the United States, to dictate strategy, and to scuttle ongoing settlement negotiations.

\section{The bureaucratization of justice}

The Bhopal Act was a limited measure. While it left open the establishment of a compensation commission, it largely presupposed that the solution to the disaster would be achieved through the traditional litigation process. Its primary effect was to shift the conduct of the litigation from the individual victims to the government. Even this limited innovation proved highly problematic.

Had the litigation proceeded further than it did in the United States, or had India sought to enforce a judgment there, the legality of the Indian statute would likely have become a major issue. Notions of individual rights and due process might well have been deployed to undermine India's claim to parens patriae power. American courts have held that the parens patriae jurisdiction is appropriate only when the state has an interest in the litigation independent of the individual interests of the citizens; and that the procedure may not be exercised simply to collect damages for a person who is legally entitled to an individual claim. ${ }^{17}$

${ }^{16}$ Ibid. at s. 4.

17 See Hawaii v. Standard Oil Co. of Califomia, 405 U.S. 251 (S.C. 1972); Pfizer, Inc. v. Lord, 522 F.2d 612 (8th Cir. 1975); both discussed in the in-depth analysis of this issue by 
These same arguments have been raised in the Indian courts by individual victims and groups dissatisfied with the government's management of the litigation. The hostility to the Bhopal Act is based upon the same concerns that underlie the traditional distrust of class actions in mass injury suits. Opponents argue that class actions "bureaucratize" justice by taking the conduct of the litigation out of the hands of the victim..$^{18}$ The class form, they argue, cannot respond to the individual needs of the victims and cannot produce a remedy tailored to the individual. The aggregation and collectivization of claims "achieves administrative goals of efficiency, consistency, and maximum substantive output by subordinating the interests of individual victims (although not of defendant firms) to the interests of the class as a whole."19

The use of parens patriae power is further problematic because the Indian government was in a situation of considerable conflict of interest. It is arguable that various government bodies at the national, state, and municipal levels are legally implicated in the tragedy. India, itself a major owner of the Bhopal enterprise, can be viewed as lax in administering its own health and safety requirements. Apart from the Indian government's potential legal liability in the case, the Bhopal disaster was also to become a major political liability for it. And the imperatives of containing political damage control can easily conflict with the best interests of the victims.

Objections to the bureaucratization of justice become especially strong during settlement negotiations when, inevitably, at least some members of the class will be dissatisfied with the proposals. The purpose of the class action is to aggregate claims to empower individual victims who would not otherwise have access to

L.F. Butler, "Parens Patriae Representation in Transnational Crises: The Bhopal Tragedy" (1987) 17 Cal. W. Int'l L. J. 175.

18 For general analyses of the issue of class actions in mass tort litigation see Public Law Vision, supra, note 9; D. Rosenberg, "Class Actions for Mass Torts: Doing Individual Justice by Collective Means" (1987) 62 Ind. L. J. 561 [hereinafter Class Actions]; and S. Williams, "Mass Tort Class Actions: Going, Going, Gone?" (1983) 98 F.R.D. 323.

19 Class Actions, ibid. at 565-66. 
justice. The irony is that as the process nears success it comes under tremendous disaggregative pressures. Each time the government and Union Carbide came close to a settlement, the proposed agreement was met by massive protests, charges of incompetence and collusion, occasional violence, and tremendous confusion. Disempowered by the process, denied a voice, and suspicious of government motives, the victims will inevitably feel betrayed.

The bureaucratization of justice, India's potential conflict of interest, and the disempowerment of the victims were all major defects in the scheme framed by the government. But the failings of the Bhopal Act do not point in favour of a return to individualized justice. Serious as the problems were, it is crucial to remember that the majority of the victims were poor and had no other means of legal redress. The limitations of the scheme were the result of the scheme's attempt to graft a public model of administration onto a private model of litigation. The government, itself a potential litigant, simply substituted itself as lawyer for the victims, and thereby assumed only partial responsibility for the victims' welfare. The Commission did make enormous efforts to provide interim relief; however, these efforts were hindered by lack of funding, dependence upon the final outcome of the litigation, and public perception of the Commission as an adversarial government agency. By providing only limited and conditional interim relief, the scheme left the victims as stakeholders in the litigation and, at the same time, denied them an effective say about their future.

What these problems teach is that, at a minimum, the agency responsible for the litigation should have greater autonomy from the government. It should also be structured in such a way as to allow more effective communication and participation by the victims. Indeed, the victims came increasingly to rely on the various social action groups to act as watchdogs and agitators on their behalf, but these groups were consigned to the role of adversaries rather than participants. Even more ambitiously, the scheme might have separated entirely the issues of compensation and liability. By 
adopting a "superfund" model ${ }^{20}$ the victims could be guaranteed a minimum level of compensation regardless of the outcome of the litigation. Under such a model the tasks of compensation and rehabilitation need not be subject to the delays of litigation; and the government, as the only stakeholder in the litigation, increases its legitimacy as parens patriae by assuming a more complete responsibilty for the victims' welfare.

\section{B. Finding a Forum: The U.S. Litigation}

A year after the disaster, individual claims totalling 250 billion dollars had been filed in various courts in the United States. The locus of legal activity shifted to the U.S. where the claims were consolidated in the New York District Court. A preliminary issue of major importance now presented itself: whether the courts of the United States should involve themselves in the litigation on the basis that the parent company was an American corporation.

On 1 July 1985 the Union Carbide Corporation brought a preliminary motion to dismiss the actions from American courts on the grounds of forum non conveniens. By now, the government of India had taken on a major role in the litigation under the Bhopal Act. It responded to UCC's motion by arguing that justice could only be obtained in American courts. These arguments were greeted with reactions ranging from outrage to resignation by the Indian media, bench, and bar. The Chief Justice of the Indian Supreme Court said, "It is my opinion that these cases must be pursued in the United States ... It is the only hope these unfortunate people have."21 Union Carbide, anxious to avoid

20 See, for example, the Comprehensive Environmental Response, Compensation, and Liability Ach 42 U.S.C.S., ch. 103, \$\$ 9601-9657 (1982 \& Supp IV, 1986). Note that this scheme applies by and large to clean-up costs and does not extend to compensation for personal injuries. See also the new Ontario "Spills Bill," Part IX Environmental Protection Act, R.S.O. 1980, c. 141, ss 79-112.

21 M. Galanter, "Legal Torpor: Why So Little Has Happened in India After the Bhopal Tragedy" (1985) 20 Tex. Int'l L. J. 273 at 287 [hereinafter Legal Torpor] quoting Stewart, "Why Suits for Damages Such as Bhopal Claims are Very Rare in India" Wall Strect Journal (23 January 1985) 1. 
American tort doctrine, American damage awards, and American juries argued that the United States was not the proper forum and began to paint the picture of an innovative, sophisticated, and vigorous Indian legal system, well up to the task at hand. ${ }^{22}$

\section{Inconvenient forum}

The American chapter of the litigation effectively came to an end on 12 May 1986 when Judge John Keenan of the New York District Court sent the case back to India. ${ }^{23}$ Judge Keenan's conclusion - which was upheld in substance by the Court of Appeal $^{24}$ - was that India offered an adequate alternate forum and that both private and public interest concerns favoured India as the proper forum. He held that the Indian connection to the litigation far outweighed the American. The parent corporation, he concluded, had little involvement in the Indian operation immediately prior to the disaster, and victims, witnesses, and documentary evidence were located primarily in India. He found that the plant was extensively regulated by Indian law and that it would be paternalistic to evaluate those laws or to impose American standards of health and safety. He held that the Indian legal system and judiciary had the capacity to deal with complex tort claims such as those arising out of Bhopal and concluded that

to retain the litigation in this forum ... would be yet another example of imperialism, another situation in which an established sovereign inflicted its rules, its standards and values on a developing nation. This Court declines to play such a role ... To deprive the Indian judiciary of this opportunity to stand tall before the world and to pass judgment on behalf of its own people would be to revive a history of subservience and subjugation from which India has emerged. 25

\section{2}

The parties' arguments are collected in Baxi \& Paul, supra, note 4.

23 In re Union Carbide Corp. Gas Plant Disaster, 634 F. Supp. 842 (S.D.N.Y. 1986) [hereinafter Union Carbide, U.S. District Court].

${ }^{24}$ In re Union Carbide Corp. Gas Plant Disaster, 809 F.2d 195 (2d Cir. 1987) [hereinafter Union Carbide, U.S. Court of Appeal].

25 Union Carbide, U.S. District Court, supra, note 23 at 867. 
2. A critique

While Judge Keenan's decision sounds reasonable from one perspective, he may have tipped his hand when he concluded that the American interest in the litigation was only ephemeral and that the expense of a trial should not be borne by the American taxpayer. These comments prompted Upendra Baxi, a prominent Indian legal scholar, to refer to Keenan's judgment as "Dow-Jones jurisprudence":

As long as no harm occurs to Americans ... how can the public interest of the United States be ever adversely affected? Indeed, it is best served by dumping dangerous technology on poor countries ... A more rigorously conservative view of the public interest concerns of the United States, and a more joyous surrender of power and discretion to do justice, than Justice Keenan's would be difficult to locate in the recent annals of American jurisprudence. ${ }^{26}$

Baxi points out that the conclusion that the U.S. had no real interest in the litigation fails to take seriously that India's claim was against the American-based multinational and not its Indian affiliate. Judge Keenan's approach localizes and trivializes the disaster by presupposing that the parent company would not, and should not, be held responsible for its overseas operations.

Measured against the criteria suggested above, the response of American law to the disaster can only be labelled a failure. It prolonged the litigation, and resulted in a substantive principle whereby home states are not responsible for supervising the activities of their corporations abroad. The principle may even encourage corporate irresponsibility. Keenan J. was right to indicate that the blanket imposition of American standards on a multinational's overseas operation might be insensitive to the needs and policies of the host country. Indeed, this is one of the most problematic features of the ongoing attempts to formulate international codes of conduct for transnational business. ${ }^{27}$ But the

26 U. Baxi, Inconvenient Forum and Convenient Catastrophe: The Bhopal Case (Bombay: N.M. Tripathi, 1986) at 29.

27 See Lutz, supra, note 7; G. Handl, "Environmental Protection and Devclopment in Third World Countries: Common Destiny - Common Responsibility" (1988) 20 N.Y.U. J. Int'l L. \& Pol. 603. 
refusal to play any supervisory role simply entrenches double standards for safety whereby ultrahazardous products and processes are exported from developed to developing countries, and multinationals engage in practices abroad that would not be tolerated in their home countries. A judicial affirmation of this status quo confirms to the people of the third world that their lives are considered cheap.

The refusal by American courts and regulators to assert interest in U.S. corporate activities abroad, out of respect for sovereignty, is somewhat disingenuous. Extraterritorial regulation of foreign affiliates is an established instrument of U.S. domestic and foreign policy when it is deemed suitable, for example to enforce anti-trust policy or trading bans on hostile countries. To treat health and safety matters as the purely "private" concerns of the corporation and its host country ignores that the most significant arena in which modern-day imperialism is played out is the international economy. The decision not to regulate MNC's does not avoid, but rather licences this form of domination. Indeed, insofar as the decision defers to Indian law and the apparent autonomy of Union Carbide's Indian operation, it may encourage the parent corporation to further reduce its involvement in supervising the health and safety of its operations in third world countries. And Judge Keenan's message has not fallen on deaf ears. The general counsel for a major multinational has recently said:

Ironically the existence of pervasive and intrusive regulation by the foreign jurisdiction may have the effect of reinforcing a district court's willingness to dismiss a case brought by foreign plaintiffs. This type of regulation, while bothersome as a compliance matter, may have the unintended benefit of reinforcing the local interest in the controversy 28

The conclusion drawn is that legal responsibility can be avoided by emphasizing local government regulation and delegating to the subsidiary "as much autonomy as possible concerning operating

28 A.C. Seward III "After Bhopal: Implications For Parent Company Liability" (1987) 21 Int'l Law. 695 at 706. A.C. Seward III is Associate General Counsel and Secretary for Upjohn International Inc. 
matters. ${ }^{1129}$ Multinationals should maintain strategic control from afar but leave operations in the hands of local managers and safety in the hands of the host government. Control can thus be maintained, while responsibility avoided. Arguably, this is precisely what happened in Bhopal.

Finally, while a "hands-off" approach may be justified on the basis of a respect for Indian sovereignty and its legal process, American law remained a brooding presence in the background and a significant limitation on the Indian legal process. Any judgment of an Indian court would have to be enforced in the United States; and as Judge Keenan said in his decision, recognition of an Indian judgment would be contingent upon its conformity to "minimal requirements of due process." ${ }^{\text {"30 }}$ While the "innovativeness" of the Indian courts was one of the reasons for returning the case to India, that same innovativeness was later characterized by Union Carbide as a failure of due process and as a sufficient reason not to undertake to submit to Indian jurisdiction.

\section{THE LITIGATION IN INDIA}

Having successfully returned the case to India, Union Carbide reversed its position. Indeed, even before leaving the American courts it sought to revoke its consent to abide by Indian jurisdiction on the basis that "Indian courts, while providing an adequate alternate forum, do not observe due process standards that

29 [emphasis omitted]. See Seward, ibid at 706-7. "The analysis followed by Judge Keenan suggests a need for a clear delineation of responsibility between headquarters management and subsidiary personnel, with delegation to subsidiary management of as much autonomy as possible concerning operating matters and restriction of headquarters management to strategy and policy issues."

30 Union Carbide, U.S. District Court, supra, note 23 at 867 . This specific wording of this condition was removed by the Court of Appeal on the basis that it might imply a lesser standard to be met for enforcement. The Court of Appeal stated that: "Any denial by the Indian courts of due process can be raised by UCC as a defense to the plaintiff' later attempt to enforce a resulting judgment against UCC in this country." See Union Carbide, U.S. Court of Appeal, supra, note 24 at 205. 
would be required as a matter of course in this country. "131 Having expressed compassion for the victims, Union Carbide refused to abide by orders to pay interim compensation. Having convinced U.S. courts not to export American justice to India, Union Carbide then sought to export American notions of due process to resist judicial efforts in favour of the victims.

Union Carbide, like most other observers, knew that, without radical innovation, Indian tort law and civil procedure were not likely to provide a speedy resolution to the dispute. While the company originally denied the defects of the Indian legal system, it could not have been surprised that four and a half years after the disaster, the case had still not even reached discovery, much less a trial on the merits.

As India's own critique of its legal system revealed, the procedural and substantive problems were bound to be formidable. ${ }^{32}$ The law of torts in India remains unsystematic and relatively undeveloped. It is entirely neglected by many works on Indian law and is infrequently resorted to by the populace. ${ }^{33}$ There are no civil juries and damage awards are very low. Courts are overworked and understaffed and delays are long. Pretrial procedures are limited in comparison to the United States, discovery is minimal, and the collection of evidence is difficult. Judge Keenan had recognized this latter problem, and as one of the conditions of ordering the case back to India, he had required Union Carbide to submit to discovery

31 Union Carbide, U.S. Court of Appeal, supra, note 24 at 204.

32 The following is distilled primarily from affidavit by Marc Galanter on Behalf of the Government of India's Motion in Opposition to Union Carbide's Motion to Dismiss, reprinted in Baxi \& Paul, supra, note 4 at 161. See also Legal Worlds, supra, note 13 and Legal Torpor, supra, note 21 .

33 Legal Worlds, supra, note 13 at 296 . Galanter notes that a fifty-year survey found that cases of malicious prosecution outnumbered those for negligence (from R. Ramamoorthy, "Difficulties of Tort Litigants in India" (1970) $12 \mathrm{~J}$. Indian L. Inst. 313); and in his own tenyear survey Galanter found only fifty-two reported tort cases that were other than motor vehicle accidents. Of these, only twenty-two were negligence cases and none of these involved products liability or industrial or chemical mishaps. The cases took an average of twelve years and nine months. Average recovery of successful plaintiffs was 15,159 rupees (1,263 dollars). 
by India according to the broader American rules. ${ }^{34}$ On a subsequent appeal, Union Carbide had successfully applied to have this condition dissolved on the ground that it was not reciprocally imposed on India. ${ }^{35}$ There are no contingency fees, and heavy ad valorem court charges make it virtually impossible for the poor to seek legal redress. There is very little specialization in the profession and most lawyers are sole practitioners with almost no fact-finding facilities. When these obstacles are added together, it is fair to conclude, as Marc Galanter has, that "[d]isasters large and small in India typically have no legal consequences. ${ }^{136}$ Some have suggested that the virtual nonexistence of legal redress for personal injuries is an aspect of the karmic fatalism that characterizes the vision of life in India. ${ }^{37}$ Whatever the explanation, at least until now, the law of tort in India has been little more than a myth about how people would be cared for in a better world.

Notwithstanding this gloomy scenario, it is also true that when fully galvanized the Indian legal system is one of the most dynamic in the common law world. Over the past several decades, lawyers, social activists, and the courts in India have demonstrated a remarkable degree of social and legal creativity and have expended enormous effort in an attempt to make law work for the poor. Especially under the banner of Public Interest Litigation, courts have sought to enhance access to justice, expedite legal processes, and breathe substantive life into the formal promises of law. ${ }^{38}$ They have liberalized the rules of standing, provided funding for public interest activists, dispensed with formal procedural requirements, and elaborated substantive rights designed to enhance the welfare of the poor and oppressed. These rights include the right to a speedy

${ }^{34}$ Union Carbide, U.S. District Court, supra, note 23 at 867.

35 Union Carbide, U.S. Courn of Appeal, supra, note 24 at 205-6.

36 Legal Torpor, supra, note 21 at 280.

37 R. Dhavan, "For Whom? And For What? Reflections on the Legal Aftermath of Bhopal" (1985) 20 Tex. J. Int'l L. 295 at 302.

38 See J. Cassels, "Judicial Activism and Public Interest Litigation in India: Altempting the Impossible?" (1989) 37 Am. J. Comp. L. 495. 
trial, ${ }^{39}$ the right to legal aid, ${ }^{40}$ the right to a livelihood, ${ }^{41}$ a right against pollution, ${ }^{42}$ and the right to human dignity. ${ }^{43}$

Therefore, it is no surprise that during the course of the Bhopal litigation a number of innovations have been attempted. The remaining sections will very briefly review the following developments: first, the articulation of a theory of strict liability for industrial hazards; secondly the suggestion of a theory of multinational enterprise liability; and finally, the effort to devise a system of interim compensation.

\section{A. Substantive Concerns: Proof of Liability and the Standard of Care}

In September 1986 the Union of India formally filed suit against Union Carbide in the District Court of Bhopal, claiming 3.3 billion dollars. It based its claim upon misrepresentation, breach of warranty, negligence, and strict and absolute liability. It alleged that Union Carbide had provided a faulty design, that it stored excessive quantities of the lethal chemical in an inadequate containment system, and that it was aware of the toxic properties of the chemical and the hazardous nature of the operation, yet it took no steps to control the danger. Union Carbide, in turn, reiterated its sabotage theory, denied that it had any involvement in the Bhopal operation, and alleged contributory negligence by India in allowing slums to grow in the immediate vicinity of the plant and failing to enforce its own safety standards.

${ }^{39}$ Madhav Hayawadanrao Hoskot v. Maharashtra (State of) (1978), 3 S.C.C. 544, A.I.R. 1978 S.C. 1548; Hassainara Khatoon v. Home Secretary, Bihar (State of), A.I.R. 1979 S.C. 1360, 1369, 1377.

40 M. H. Hoskot, ibid.

41 Olga Tellis v. Bombay Municipal Corp. (1985), 3 S.C.C. 545, A.I.R. 1986 S.C. 180.

42 Rural Litigation and Entitlement Kendra, Dehradun v. Uttar Pradesh, State of, A.I.R. 1985 S.C. 652.

43 Francis Coralie Mullin v. Administrator, Delhi (Union Territory of) (1981), 2 S.C.R. 516, A.I.R. 1981 S.C. 746. 
Indian tort law is based on English common law. The victim of an injury must prove not only that the defendant caused the harm, but also that the defendant was at fault or negligent by failing to use reasonable care to prevent the injury. To establish liability in negligence it would have to be shown that UCC had a duty to oversee its Bhopal operation; that it breached that duty by failing to use reasonable care; that this failure caused the gas leak; and that the gas caused the damage suffered by each individual victim. These requirements, coupled with limited production and discovery procedures, make the problems of proof in a mass disaster case daunting indeed. It is not too surprising that throughout the entire process of the litigation, it never became clear exactly how the disaster occurred.

Even if the standard of strict liability in Rylands v. Fletche ${ }^{44}$ applies, the battle is uphill. UCC would argue, for example, that the manufacture of pesticides is neither ultra-hazardous nor a "non-natural" use of land. ${ }^{45}$ UCC's steadfast insistence on a sabotage theory might also provide a defence to strict liability based on the notion that the damage was caused by the wilful intervention of a stranger and was, therefore, not the act of Union Carbide. Finally, it would continue to shift liability to other actors, including the workers and management of the local operation, the state and federal governments, and to insist on the protection afforded by its corporate veil.

The principle of strict liability has not met with great judicial favour and may be merging into the law of negligence and nuisance. ${ }^{46}$ This trend might be explained by the increased prominence of social insurance schemes as mechanisms of loss

44 (1866) L.R. 1 Ex. 265, affd (1868) L.R. 3 H.L. 330.

45 For a full analysis of the strict liability argument, see P.T. Muchlinski, "The Bliopal Case: Controlling Ultrahazardous Industrial Activities Undertaken by Foreign Investors" (1987) 50 Mod. L. Rev. 545.

46 J.G. Fleming, The Law of Torts, 6th ed. (Sidney: Law Book Company, 1983) at 307-8. 
spreading, and the lesser need for judicial invention. ${ }^{47}$ If so, then given the absence of social insurance in India, the Indian courts would arguably be justified in adopting a more activist stance. This is precisely what they have done.

\section{Shriram fertilizers}

Exactly one year after the Bhopal disaster, a leak of toxic oleum gas from the Shriram fertilizer factory in north Delhi claimed the life of one person and injured hundreds of others. The Delhi administration immediately closed down the plant, and a public interest application was brought on behalf of the victims to the Supreme Court.

In December 1986, Bhagwati C.J. (retired) gave the court's ruling on the issue of liability. ${ }^{48}$ While accepting that the chemical industry was necessary to the economy of India, he reasoned that the social costs of industrial development should not be borne by individual workers and citizens. He held that an enterprise engaged in hazardous or inherently dangerous activities owes an "absolute and non-delegable duty to the community" to ensure that no harm is done:

[I] any harm results on account of such activity, the enterprise must be absolutely liable to compensate for such harm and it should be no answer to the enterprise to say that it had taken all reasonable care and that the harm occurred without negligence on its part. Since the persons harmed on account of the hazardous or inherently dangerous activity carried on by the enterprise would not be in a position to isolate the process of operation from the hazardous preparation of substance or any other related element that caused the harm the enterprise must be held strictly liable for causing such harm as part of the social cost for carrying on the ... activity. 49

The court found further support for this principle since "the enterprise alone has the resource to discover and guard against

47 Fleming, ibid, citing Tylor, "The Restriction of Strict Liability" (1947) 10 Mod. L. Rev. 396, and Friedmann, "Social Insurance and the Principles of Tort Liability" (1949) 63 Harv. L. Rev. 241.

48 M.C. Mehta v. Union of India, A.I.R. 1987 S.C. 1086.

49 Ibid. at 1099. 
hazards or dangers and to provide warning" 50 and the victims are not in a position to overcome the problems of proof.

In the context of environmental and industrial hazards, a principle of absolute liability ensures that the full social costs of production are considered in making risk management decisions. It relieves the claimant of the near impossible tasks of proving factual causation and negligence, affirms the value of compensation to innocent victims of industrial progress, and is consistent with the notion of "polluter pays."51 Internationally, the Shriram judgment was acclaimed as an important contribution to the common law, and locally it was seen to have bestowed an important bargaining endowment on the victims' side of the litigation. It was greeted with enthusiasm by many activist groups and was seen to provide a precedent that might hasten a speedy and more generous settlement. That these hopes proved unfounded is one of the more significant lessons of Bhopal.

\section{B. Allocating Responsibility: MNCs and the Corporate Veil}

A standard of absolute liability does not, of course, advance the case very much if Union Carbide is not the proper party to the dispute. UCC maintained throughout that while it was the majority owner of Union Carbide of India Ltd (UCIL), the two companies are separate corporate entities and that its relationship with the Indian facility was at arm's length. It thus presented itself as a passive investor in the Indian operation, exercising no control or authority over its day-to-day operations. Indeed, lawyers for UCC denied that there is any such entity as a "multinational corporation" or that the American company had any operations outside the United States. UCC maintained that the relationship between itself and UCIL was so remote that it would be both unjust and illegal to hold it responsible for damage caused by faulty operation of the Bhopal plant.

\footnotetext{
${ }^{50}$ Ibid.

51 For recent legislation in this direction see the new Ontario "Spills Bill," supra, note 20.
} 
The legal issues here are misleadingly simple. First, does a parent corporation have a direct duty to manage its subsidiaries in a competent fashion? And secondly, apart from its direct duties to the community, is the parent company vicariously or otherwise liable for the acts of its subsidiaries?

India sought to implicate the parent company on both these fronts. It alleged that Union Carbide owed a direct duty in both tort and contract to supervise the Bhopal operation, to maintain standards, to update safety systems, to provide current information, and to warn of hazards. Perhaps more importantly, India sought to establish the principle that, in some circumstances, a parent company must be held responsible for the delicts of a subsidiary. This is the theory of multinational enterprise liability. The argument is based upon the proposition that the web of companies under the financial control of the multinational are part of a single economic group with common objectives. Just as the parent corporation maintains control over the group, so must it maintain financial responsibility for its various endeavours. 52

The American courts had not been much impressed by India's argument that a multinational might be responsible for the operations of its subsidiary. Both Judge Keenan and the Court of Appeal accepted Union Carbide's evidence that it had not been involved in the construction and operation of the Bhopal plant, that its relationship with UCIL was at arm's length, and that the Indian operation was quite autonomous from UCC control. Perhaps not surprisingly, Indian courts have revealed that they have a different view of the realities of multinational business in the developing world.

52 See J.L. Westbrook, "Theories of Parent Company Liability and the Prospects for an International Settlement" (1985) 20 Tex. Int'l L. J. 321; D. Aronofsky, "Piercing the Transnational Corporate Veil: Trends, Developments and the Need for Widespread Adoption of Enterprise Analysis" (1985) 10 N.C. J. Int'l L. \& Comp. Reg. 31; T. Hadden, R.E. Forbes \& R.L. Simmonds, Canadian Business Organizations Law (Toronto: Butterworths, 1984) at 639-52. 
1. Water down the Ganges

Much to Union Carbide's horror, there has been some indication that the Indian courts will be willing to lift the corporate veil in the Bhopal case. In related interlocutory proceedings concerning its liability to pay interim relief to the victims, Union Carbide argued that the case against it should be dismissed on the basis of its separate corporate personality. ${ }^{53}$ However, in the Madhya Pradesh High Court, Seth J. suggested that "much water has flown down the Ganges since it was first held in Salomon v. Salomon ... as an absolute principle that a corporation or company has a legal and separate identity of its own."54

Seth J. noted the increasing number of exceptions to the principle of separate corporate personality and suggested: "It may be that in course of time these exceptions may grow in number and to meet the requirements of different economic problems, the theory about the personality of the corporation may be confined more and more." ${ }^{155}$ Thus, the corporate veil may be lifted where

fraud or improper conduct is intended to be prevented or a taxing statute or a benevolent statute is [s]ought to be evaded or where associated companies arc inexricably connected as to be in reality part of one concem. It is neither necessany nor desirable to enumerate the class of cases where lifting the veil is permissible. 56

Seth J. concluded on the basis of the evidence adduced so far that UCC had real control over the Bhopal plant. It was the majority shareholder, and controlled the composition of the board of directors and management of the Indian company. If, as Union Carbide argued, it chose not to involve itself in the operation and

53 Union of India v. Union Carbide Corp. Ltd (M.P.H.C.) [Unreported] (manuscript available from the author).

54 Ibid. at para. 14.02.02 [emphasis added].

55 Ibid.

56 Ibid. at para. 14.02.03 quoting from Life Insurance Corporation of India v. Escorts Lud A.I.R. 1986 S.C. 1370. 
safety of the foreign company, that was "entirely its choice and such a policy could not absolve it from its liability."157

Limited liability is recognized as a useful instrument for the allocation of risk and the generation of capital for industrial ventures. By limiting the potential liability of investors, the law provides an incentive to investment and avoids unfairly surprising remote owners with undue managerial responsibility or financial risk. An outright abolition of the notions of corporate personality and limited liability could well have serious adverse consequences for a developing nation's ability to attract international investment. Multinationals will cry foul and will warn of capital flight. They will argue that such an approach would penalize offshore investors and would make it impossible to evaluate the level of financial risk on any investment or project. The enterprise liability approach threatens to rewrite the responsibilities undertaken by the parties, for example, by turning a simple technology transfer into a joint venture or partnership. It fails to recognize that many affiliates and subsidiaries really do operate in an autonomous fashion and threatens to force multinationals to take a role in domestic management beyond what it, or even the host state, desires.

But both the benefits of limited liability and the objections to enterprise liability may be overstated. Especially in the case of a multinational business organization, the corporate form can too easily be used to avoid taking responsibility for risk. By pursuing their purposes through a network of formally independent subsidiaries, a multinational's assets can be widely dispersed and placed beyond the reach of the law. Through transfer pricing techniques, high-risk subsidiaries can be maintained on the borderline of solvency. Unlike commercial creditors, victims of corporate torts do not know in advance the risk of "dealing with" a limited liability corporation, and can not protect themselves against that risk. ${ }^{58}$ To hold the parent liable is often the only way to

57 Ibid. at para. 14.03.02.

58 Thus, for example, Welling says that the argument for limited liability is not strong in the case of torts as opposed to consensual debts. A contractual creditor is aware that a limited liability company is being dealt with, can investigate its credit, demand additional security, or accept the risk of insolvency. A tort creditor is a stranger who has no such 
ensure full compensation for these victims and to encourage the parent company to exercise greater responsibility in controlling its foreign operations.

The principle of limited liability is an instrument of public policy and is ultimately justifiable only when grounded in the public good. In the Bhopal case, the calculus of public benefit points toward a finding of liability. Union Carbide was the primary economic beneficiary of the hazardous activity and the victims are blameless. The parent company's control of technology, finances, the board of directors, and company management gave it effective control over the direction and operation of its subsidiary. The parent company's choice to abdicate this power is as much a reason for imposing liability as denying it. As between the parent company and the subsidiary it is impossible to pinpoint responsibility for particular risks. Victims are not in a position to isolate which part of the monolithic concern caused the harm or should have prevented it.

Most advocates of enterprise liability recognize that the principle should not be absolute. For some purposes, the foreign affiliate will be an independent company and to ignore its autonomy in some spheres of its operations would be inappropriate and lead to a flight of capital..$^{59}$ However, in other spheres, especially those concerning workplace safety and risk management, there should be minimum standards of parent company responsibility. ${ }^{60}$ Such an approach to enterprise liability would go some way toward eliminating the lower standard of safety in developing countries. If suitably defined, the principle might not significantly increase investor risk. It would put the parties on notice as to what their obligations are and would remove the incentive to allow an orphan operation to run on while imposing unacceptable hazards. The

opportunity. See B. Welling, Corporate Law in Canada: The Goveming Principles (Toronto: Butterworths, 1984) at 146-49.

59 For example, Aronofsky suggests that there should be a presumption of parent company responsibility that can be rebutted where the parent company can show that "its conduct and economic status within an enterprise are completely unrelated to the dispute before the court." Supra, note 52 at 32 .

${ }^{60}$ See, for example, Westbrook, supra, note 52. 
principle might allow, and indeed encourage, the parties to spell out more carefully in the initial agreements what their respective obligations are.

It is too early to say what effect absolute and enterprise liability decisions will have on the investment climate in India. In recent negotiations with the Union of India, potential investors have raised the Bhopal judgments as a concern. ${ }^{61}$ It has been reported that one company has postponed its investment decision partly out of its concern on these grounds ${ }^{62}$ and the government has been urged to relax the law. While this is not politically feasible at this time, officials have noticed a slowdown in the rate of growth of U.S. investment and acknowledge the possible costs of the Bhopal judgments. ${ }^{63}$ On the other hand, it should also be realized that these "radical" reforms have not yet translated into any cost for industry, and as one director of a large multinational said, "I doubt whether any chemical company in the world defers an investment in India on this ground. Investments are more of an economic question. ${ }^{164}$

C. And In the Meantime, What of the Victims?

Each one of the developments described have been greeted with enthusiasm. However, a crucial question in any litigation is how to care for the victims until final compensation is available. This problem is particularly acute in Bhopal where the victims are overwhelmingly poor and social welfare systems are unavailable to provide basic care. As long as three years after the disaster, the case had not come to trial and the victims had received almost no interim assistance. Lawyers for both parties had been exchanging

\footnotetext{
61 S.S. Suri, Joint Secretary, Department of Chemicals and Petrochemicals, Ministry of the Environment (personal interview, 6 December 1989).

62 Economic Times (27 October 1989) 8.

63 Suri, supra, note 61.

64 Statement by W. Grubman, Director of Unilever, reported in Economic Times (27 October 1989) 8 .
} 
revised pleadings and bringing numerous interlocutory motions. Union Carbide had taken the position that the action could not proceed until India provided full particulars of the extent and nature of the victims' injuries. Such a request, reasonable in the context of ordinary litigation, was clearly impossible to satisfy in the case of Bhopal. The machinery set up by the Bhopal Act to document the claims was handicapped by inadequate resources and insufficient knowledge about the short-term and long-term effects of MIC poisoning; and had been overwhelmed by the number of claims and the enormity of its task.

Out of frustration with the proceedings, one of the social activist groups brought an application seeking to have the litigation transferred to the Madhya Pradesh High Court for expedited proceedings. ${ }^{65}$ The court refused to grant the petition. It accepted that in such complex litigation, lengthy pre-trial proceedings were inevitable as the parties sought to frame the issues for trial. It denied that UCC and the government were unreasonably delaying the proceedings. However, the court did say:

Before parting, we must direct the parties to fully co-operate in the early disposal
of the claim cases in order that the victims of the tragedy get justice without further
delay. We also direct the District Judge to examine what interim relief can be
granted to ameliorate the conditions of the victims and minimise the human
sufferings, especially of the legal heirs of 2500 or so persons who died in the
tragedy and those who have been permanently disabled and are not in a position
to earn their livelihood and having nothing to fall back upon. 66

Throughout 1987, Judge Deo of the Bhopal District Court had been pressing the parties to reach an out of court settlement. On 18 December 1987, when the most recent settlement negotiations broke down, he ordered Union Carbide to pay 3.5 billion rupees (270 million dollars) in interim compensation to the Bhopal victims. He commented that "It cannot be denied that an unprecedented tragedy took place on account of a deadly leak ... Can the gas victims survive till the time all the tangible data with

${ }^{65}$ Union Carbide Corporation v. Union of India, A.I.R. 1988 M.P. 206.

66 Ibid. at 210. 
meticulous exactitude is collected and adjusted in fine forensic style for working out the final amount of compensation with precision?"167

Union Carbide spokespersons responded with anger, repeating their claim that the gas leak was the result of sabotage by an Indian employee of UCIL and claiming that the court order amounted to awarding damages without a trial. The judgment was immediately appealed by Union Carbide to the Madhya Pradesh High Court. Lawyers for UCC argued that the order had no basis in law, that it was punitive in nature, and that in making it, Judge Deo had succumbed to political pressure, substituting an emotional response in place of legal judgment.

1. The revenge of the colonies

On 4 April 1988, Justice S.K. Seth of the Madhya Pradesh High Court. upheld the order, though he reduced the amount. 68 Justice Seth took as his springboard section 20 of the English Administration of Justice Act which provides for interim compensation in certain circumstances. ${ }^{69}$ This provision, passed well after Indian independence, is not part of Indian law. However, Indian law at independence, like Canadian common law, was derived and adapted from the English according to the principles of "justice, equity, and good conscience." This principle, familiar to many ex-colonial nations, is generally understood to mean the rules of English law if found applicable to local society and circumstances.

Indian courts have previously modified their common law following statutory reform in England. One example is the case of Vidya Devi v. M.P.S.R.T. Corp. ${ }^{70}$ in which the court refused to apply the traditional common law doctrine of contributory negligence.

67 Union of India v. Union Carbide Corporation; Gas Claim No. 1113 of 1986 (17 December 1987, Bhopal Dist. Ct) at 14-15 [unreported] (Manuscript available from the author).

\footnotetext{
${ }^{68}$ Supra, note 53.

69 The Administration of Justice Act (County Court) 1969, c. 58.

70 A.I.R. 1975 M.P. 89.
} 
The English doctrine had, by this time, been altered by the Contributory Negligence Act and there was no equivalent legislation in India. However, the Indian Supreme Court held that the law of India must also be changed to conform with the general principle of justice, equity, and good conscience.

There is no doubt a presumption that a rule of common law is in consonance with justice, equity and good conscience. But how can that presumption continue if the country of its origin has itself rejected the rule and has made new rules in its place. If the new rules of English law replacing or modifying the common law are more in consonance with justice, equity and good conscience, it would be open to us to reject the outmoded rules of common law and to apply the new rules. 71

Following this reasoning, Justice Seth concluded that a principle of interim compensation could appropriately be adopted in the case at hand.

It does not require much of an argument to accept that the intervening period between commencement of an action and its ultimate trial in a suit for damages especially when based on a tort cause[s] a greater hardship in a developing country like India than in a developed country like England. As such, there exist[s] no valid ground why the abovesaid set of statutory rules ... could not be adapted with suitable modifications as a part of Indian common law and applied to the Bhopal suit. 72

Given the evidence adduced so far about the causes of the disaster, the control exercised by UCC over UCIL, and the Shriram principle of absolute liability, Seth J. concluded that a prima facie case had been made out against the parent corporation. Thus, it was appropriate to require UCC to provide interim relief.

As throughout the litigation, Union Carbide lawyers objected to the "lawlessness" of the Indian courts in going beyond precedent to forge a principle of absolute liability, to pierce the corporate veil, and to order interim compensation. They intimated that they would not comply with the order and would resist its enforcement in the United States on the grounds that it failed to comply with "due process." While much of this was posturing, Union Carbide's objections will strike many North American lawyers as quite

\footnotetext{
71 Ibid. at 92 .

72 Union of India, supra, note 53 at para 13.01.07.
} 
reasonable since they are based upon widely shared cultural assumptions about the rule of law.

Yet, while it is technically correct to say that Justice Seth's order was novel, it was no more novel than other remedies the courts have fashioned to do justice in particular cases. For example, the Mareva injunction ${ }^{73}$ and Anton Piller orders ${ }^{74}$ are widely used, and equally draconian, pre-trial remedies forged by judicial legislation to protect plaintiffs facing a drawn-out trial. ${ }^{75}$ Similarly, the notions of absolute responsibility for hazardous activities and enterprise liability are not simply "Third World brainstorm[s]," ${ }^{16}$ but have a respectable toehold in North American common law and legislation. Perhaps more importantly, there is a certain ethnocentricity in imposing the North American legalistic understanding of the judicial function upon Indian courts. In their effort to make law work for the poor, Indian judges have departed considerably from the traditional positivist understanding of law, rejecting the "bureaucratic tradition" of rule-bound adjudication. As the former chief justice said, legalism is a myth designed to insulate judges from popular scrutiny. ${ }^{77}$ Instead, many Indian judges perceive that their task is to alleviate human suffering and achieve social justice. In pursuing this task, they frequently go beyond the judicial role as understood in England and North America, while maintaining tremendous popular and political legitimacy. ${ }^{78}$ Union Carbide's

${ }^{73}$ Mareva Compania Naviera S.A. v. Intemational Bulkcarriers S.A., [1975] 2 Lloyd's Rep. 509 (C.A.).

74 Anton Piller KG v. Manufacturing Processes Ltd, [1976] Ch. 55 (C.A.).

75 The order was, perhaps, defective in that while it was interlocutory in nature it envisaged no mechanism whereby Union Carbide could claim reimbursement in the event that they should win at trial. The simple expedient of requiring an undertaking from the Union of India to this effect would have made it far more palatable. However, given that the application had been brought, not by the government, but by an intervenor, and because of the large sum at stake, such a requirement was not feasible.

76 Westbrook, supra, note 52 at 324.

77 P.N. Bhagwati, "Judicial Activism and Public Interest Litigation" (1985) 23 Colum. J. Transnat'l L. 561.

78 See Cassels, supra, note 38. 
primary argument for the case's dismissal from the U.S. was that the Indian judiciary is capable of substantial innovation and can deal with a large-scale disaster. Given this argument, one might be excused for thinking that it would ill-behoove Union Carbide to later object to the anti-legalistic features of the Indian legal system.

\section{SETTLING A DISPUTE}

\section{A. Settling}

Following the interlocutory decision of Justice Seth, Union Carbide repeated its now familiar line that the judgment was bound to lead to further litigation on the basis that Justice Seth appeared to have "virtually decided the liability question" and had violated the company's right to due process. ${ }^{79}$ The company appealed the order once again. This was the first time the Supreme Court of India obtained jurisdiction in the Bhopal case.

In the Supreme Court, the procedural and substantive issues merged. Government lawyers apparently decided that the only way to support the interlocutory judgment was to demonstrate that any final decision would clearly place liability upon UCC. The appeal thus assumed the proportions of a full-blown trial on the merits. All the parties were clearly unhappy with this development. The factual basis for the arguments was insufficiently developed to enable UOI to present its arguments, to allow UCC to respond, or to allow the court to decide. UOI was forced to make the legal argument that, regardless of how the accident happened, and irrespective of the connection between UCC and its subsidiary, UCC was legally responsible for the accident. UCC argued that this was simply an untenable legal position. It objected to the factual theory presupposed by this argument, to the introduction of new evidence in appellate proceedings, and to the legal theory presented by the government. In particular, it attacked the Shriram judgment as politically motivated judicial legislation that was out of line with Indian law.

79 "Carbide Told to Pay $\$ 195$ Million" New York Times (5 April 1988) D1. 
On 14 February 1989, after four months of preparation and oral argument, Chief Justice R.S. Pathak interrupted a government lawyer's argument to order Union Carbide to pay 470 million dollars in damages. ${ }^{80}$ He said that in light of "the enormity of the human suffering occasioned by the Bhopal gas disaster and the pressing urgency to provide immediate and substantial relief to victims of the disaster" the case was "pre-eminently fit for an overall settlement. ${ }^{181}$ The order was in final settlement of all claims and would discharge Union Carbide from all future civil or criminal liability. Both sides greeted the ruling with enthusiasm.

It is unlikely that the final judgment was truly "imposed" by the court. Indian courts involve themselves more intimately in the litigation process than American or Canadian courts, but they do not generally "impose settlements" on the parties. The government and Union Carbide had been engaged in a series of secret talks for several weeks; and, it has been suggested, both accepted the court ruling without consulting their clients and "with an alacrity indicating a prior out-of-court agreement. ${ }^{\text {"82 }}$ Many have speculated that the interposition of the Supreme Court into the settlement may have been a formal move designed to enhance the credibility of the settlement and to protect the parties - especially the government from criticism. A national election was approaching in India, and, as one government official said: "We feel that once the Supreme Court says it's fair, the government will be on a strong wicket. ${ }^{183}$

The settlement seemed clearly to be a victory for Union Carbide. On the day it was announced, the price of its shares on the New York stock market rose by two dollars. The amount of the award is paltry in comparison to the government's claim for 3.3 billion dollars and Union Carbide's share is no more than the current value of the 350 million dollars for which it had offered to

80 Union Carbide Corporation v. Union of India, (1989) 1 S.C.C. 674; S. Hazarika, "Bhopal Payments by Union Carbide Set at $\$ 470$ Million" New York Times (15 February 1989) A1 \& D3.

\footnotetext{
81 Union Carbide, ibid. at 675.

82 "Settling for Less" Far Eastem Economic Review (2 March 1989) 27.

83 Asian Wall Street Joumal (15 February 1989).
} 
settle the suit in 1986. It is approximately the same amount (present value) of the 500-650 million dollars in staggered payments that Union Carbide was rumoured to have offered in November 1987. These negotiations had collapsed in the face of protests organized by victims groups and other social activists.

Why settle? With elections approaching, the case was clearly a political liability for the Indian government. The case had still not come to trial in the District Court and the litigation promised to drag on indefinitely. Even if the government had won on the issue of liability, it is not clear what damages it would have recovered, or that it would have been able to enforce the judgment in the American courts. UCC had refused to submit to the jurisdiction of the Indian Supreme Court. It had also intimated that it would resist enforcement of any judgment in the United States, assuming (quite correctly) there was a good chance that American courts would view the order as suspicious and as failing to comply with the "minimal due process" requirement.

Opposition politicians, victims' groups, and social activists immediately condemned the settlement as woefully inadequate and as confirmation that third world life is cheap. The settlement provoked mass protests by victims' groups and prompted the opposition parties to walk out of parliament. Twenty-five hundred survivors made the journey by train from Bhopal to Delhi to protest. Two prominent former Supreme Court judges condemned the settlement; one, P.N. Bhagwati, concluded that "the multinational has won and the people of India have lost. ${ }^{184}$ The critics of the settlement were, in turn, chastised for building unrealistic hopes for the victims, being insensitive to their immediate needs, and placing the desire for a novel legal precedent above the necessity of alleviating suffering.

The basis upon which the settlement was calculated was not known for some time. Its adequacy was attacked by comparing it to

84 P.N. Bhagwati, former Chief Justice of India, "Travesty of Justice" India Today (15 March 1989) 45. See also the remarks of K. Iyer in The Hindu (6 May 1989) 8: "Obviously the judges shared the concern for the victims and were worried by the tantalizing length of a looming, looney litigation with a foreign jurisdiction and Keenan jurisprudence to upset Bharat justice. Probably, Carbide blackmail, in the context of $\mathrm{UCl}$ assets being but a poor sum, that battles would be waged in the U.S. to delay and defeat the Delhi decree oppressed the naive psyche of the brethern into greeting any settlement as a fair adjustment." 
the Johns-Manville asbestos settlement of 2.5 billion dollars (to 60,000 victims), and the A.H. Robbins (Dalkon Shield) settlement of 2.9 billion dollars (to 195,000 victims). Critics alleged that the documentation of injuries was not complete; and that the figures used radically underestimated the number of victims and the amount that would be needed to care for them. Little is known about what the long-term effects of the poison gas are, how many more will die, and what new injuries will surface over time. The settlement was condemned as a sellout by both the government and the court and as confirmation of the "political economy of technological feudalism.. ${ }^{85}$ As one commentator concluded,

There seems to be no other explanation except that it [the government] desperately wants to propitiate foreign multinationals on which it has started relying more and more as the potent instruments for the fulfillment of its social, economic and political objectives ... The settlement sends out a clear message: multinationals can operate freely in the Indian market. ${ }^{86}$

In light of the public furore over the settlement, the government felt compelled to issue a statement to the press justifying its decision. ${ }^{87}$ It claimed that the settlement was based on an accurate estimate of both the number of victims and the amounts necessary to provide for their injuries. The government suggested that it accepted the settlement figure because it was adjudged to be fair by the Supreme Court and said: "where else could the government go for a larger sum? Nowhere in India, of course. And to try to return to the courts in the U.S.A. would have been akin to a vote of no confidence in our own judicial system. ${ }^{188}$ It argued that Union Carbide had been intransigent and "it was the government's assumption of 'parens patriae' of the Bhopal victims and its tough stand which obliged UCC to raise its figure. ${ }^{189}$ It

85 U. Baxi, "Revictimizing the Bhopal Victims" (March 1989) Lex et Juris 34 at 38.

86 B. Mehta, Indian Post (22 November 1989) 8.

87 Hindustan Times (8 March 1989) 10.

88 Ibid.

89 Ibid. 
emphasized that the case had not even reached discovery, and that to pursue the litigation would "in the most optimistic circumstances, need anywhere from 15 to 25 more years." 90 And "as for the government paying out the money first and claiming it from Union Carbide Corporation later, this would amount to giving UCC an interest-free loan for meeting its liability for the duration of the trial. ${ }^{191}$ The government claimed that the victims had been heard through various petitions to the court and concluded that

if dealing with public interest litigations is the hallmark of judicial activism, the Supreme Court's Bhopal decision is a step forward in innovative judicial activism for which the court deserves to be praised. It is a matter of pride that where foreign courts refused to take a stand, our Supreme Court dealt with a difficult matter effectively and courageously. 92

Vociferous public criticism was also levelled at the Supreme Court, causing Justice E.S. Venkataramiah to threaten to resign: "Every day you open the newspaper and you find article after article; photograph after photograph against the court. ${ }^{193}$ Such criticism, he said, was "worse than impeachment." The court also felt compelled to justify its decision, and on 4 May 1989 it issued a "judgment" explaining the settlement. ${ }^{94}$ The court explained that its primary consideration was the necessity of immediate relief for the victims. While acknowledging that important legal principles were at stake, the length of the litigation could not be justified. The "niceties of legal principles were greatly overshadowed by the pressing problems of very survival for a large number of victims. ${ }^{195}$ And in a stinging criticism of its detractors and the social activists in Bhopal, the court said:

90

Ibid.

91 Ibid.

92 Ibid.

93 Indian Express (4 March 1989) 2.

94 Union Carbide Corparation v. Union of India, (1989) 3 S.C.C. 38.

95 Ibid. at 42 . 
It is indeed a matter for national introspection that public response to this great tragedy which affected a large number of poor and helpless persons limited itself to the expression of understandable anger against the industrial enterprise but did not channel itself in any effort to put together a public supported relief fund so that the victims were not left in distress. 96

The court also remarked that it would not be influenced by "agitational measures":

Here, many persons and social action groups claim to speak for the victims, quite a few in different voices. The factual allegations on which they rest their approach are conflicting in some areas and it becomes difficult to distinguish truth from falsehood and half-truth, and to distinguish as to who speaks for whom. 97

The court explained that it had based its compensation calculations upon figures derived from previous settlement negotiations which were submitted to the court by the parties. It accepted Union Carbide's position that it would not pay more than the 350 million dollars that it had offered two years previously (plus interest). The court said that this figure would provide reasonable compensation based on the estimated number of deaths and injuries accepted in the High Court. ${ }^{98}$ The court indicated that it was reasonable to discount the total number of claims because "doubts that a sizeable number of them are either without any just basis or [were] otherwise exaggerated could not be ruled out." ${ }^{199}$ It pointed out that the total figure would provide compensation to the victims on a higher scale than the sums conventionally awarded in India in personal injury and fatal accident cases.

Finally, the court recognized that the opportunity to address important social, technological, and legal issues had been lost. But, it concluded:

[I]n the present case, the compulsions of the need for immediate relief to tens of thousands of suffering victims could not, in our opinion, wait till these questions, vital though they be, are resolved ... The tremendous suffering of thousands of

\footnotetext{
96 Ibid at 43

97 Ibid. at 51.

982660 deaths and $30,000-40,000$ serious injuries.

99 Union Carbide, supra, note 94 at 45.
} 
persons compelled us to move into the direction of immediate relief which, we thought, should not be subordinated to the uncertain promises of law. 100

\section{B. Unsettling}

Union Carbide complied with the order in March 1989 producing bank certificates to prove payment. However, in the meantime, victims' organizations filed petitions to overturn the order. The court had left open the possibility of review, remarking that "like all other human institutions, this Court is human and fallible":

[T] he case equally concerns the credibility of, and the public confidence in, the judicial process. If, owing to the pre-settlement procedures being limited to the main contestants in the appeal, the benefit of some contrary or supplemental information or material, having a crucial bearing on the fundamental assumptions basic to the settlement, have been denied to the court and that, as a result, serious miscarriage of justice, violating the constitutional and legal rights of the persons affected, has been occasioned, it will be the endeavour of this Court to undo any such injustice. ${ }^{101}$

The challenges to the settlement fell into two categories. The first relied on both general principles of natural justice and Order 23 of the Code of Civil Procedure which requires that the victims be heard prior to any settlement. They also urged that the dismissal of criminal charges was illegal in the context of civil litigation. A panel of the Supreme Court was struck on 5 March to begin hearing the petitions. It stayed the settlement order while listening to arguments for two months.

At the same time, a constitutional bench of the Supreme Court was struck to hear arguments challenging the constitutional validity of the Bhopal Act. Victims' groups argued that it deprived the victims of their fundamental right of access to justice, that the Act violated Article 21 of the constitution protecting the victims' right to life, that section 9 of the Act violated Article 14 of the constitution (equality before the law), and that the government's conflict of interest rendered it incapable of fairly representing the victims. The petitioners attacked the government's use of the

\footnotetext{
100

Ibid at 51.

101 Ibid. at 51-52.
} 
parens patriae power on the basis that it can only be used when the state is suing to enforce the rights of the state as opposed to those of individuals. A third set of petitions assumed the finality of the settlement and sought immediate interim distribution of part of the funds.

On 22 December 1989, the first constitutional bench dismissed the latter appeal, upholding the constitutional validity of the Bhopal Act. The court reasoned that the exercise of the parens patriae power was justified in the circumstances, given the powerlessness of the victims when ranged against the resources of the multinational, and that the Act did provide sufficient protection for the interests of the victims. And while the court recognized that the settlement may have been imperfect, especially insofar as the victims were not consulted, it concluded that "in view of the magnitude of the misery involved and the problems in this case" the imperfections should be tolerated. "To do a great right after all, it is permissible sometimes to do a little wrong."102

In late November 1989, the Gandhi government lost the national election to a coalition led by V.P. Singh and the pleas from the social activists that the settlement be revoked were renewed. On 12 January 1990, the new Law Minister, Mr. Dinesh Goswami, announced that the government would support the demands of the victims for increased compensation and would join in the effort to have the settlement overturned. ${ }^{103}$

\section{CONCLUSION}

Despite significant departures from traditional litigation models, when measured against the criteria suggested at the beginning of this paper, the Bhopal story is about the failure of law. It would be unfair not to acknowledge the sincere and vigorous efforts that have been made on behalf of the victims by dedicated

102 Charan Lal Sahu et al. v. Union of India, writ petition no. 268 of 1989 in U. Baxi \& A. Dhanda, eds, Valiant Victims and Lethal Litigation: The Bhopal Case (Bombay: N.M. Tripathi, 1990) 550 at 613.

103 "Bhopal Settlement Denounced" Globe and Mail (13 January 1990) A10. 
social activists and government officials. The Bhopal Gas Tragedy Relief and Rehabilitation Department has undertaken the enormous task of attempting to reconstruct a community that has been virtually decimated by the disaster. It has sought to provide assistance to the victims and to begin rebuilding the social infrastructure destroyed in the gas leak. Yet, the department is underfunded and understaffed, and its projects are buffeted by political winds. The Principal Secretary confirms that the litigation has gotten in the way of the department's efforts at every stage. ${ }^{104}$ Funding has been delayed, uncertainty makes planning extremely difficult, and the adversarial nature of the proceedings has made the collection and sharing of information almost impossible. The amount spent on litigation so far vastly exceeds any compensation received by the victims. ${ }^{105}$

Even assuming that the settlement will be upheld, it will be years before the victims receive compensation, and there is no guarantee that it will be adequate. There are currently 602,435 claims on file with the Bhopal Gas Tragedy Relief and Rehabilitation Department and each file contains up to forty pages of materials including claim forms, medical reports, and X-rays. ${ }^{106}$ The documentation that has been done so far fills four warehouses; and merely bringing the claims documents to court would require an estimated forty trucks. And assuming that the claims could be examined as quickly as one per hour, it would take over two hundred work years just to complete the paperwork. The compensation scheme contemplates the appointment of sixty judges to adjudicate the validity and quantum of individual claims. Yet, at the beginning of 1990, these officials had not been appointed and no infrastructure was in place to process claims. Given the problems of determining medical causation, it will be impossible in many cases to distinguish valid claims. And if claims are

104 S. Sathyam, Principal Secretary, Bhopal Gas Tragedy Relief Commission (personal interview, 13 December 1989).

105 Indian Post (27 November 1988) reports that UCC alone has spent 1 billion rupees so far on the litigation (approx. 58 million U.S. dollars).

${ }^{106}$ T. Allen-Mills, "Red Tape Snarls Aid to India Gas Victims" Vancouver Sun (11 March 1989) B2. 
individualized according to the severity of the claimant's injuries, lifespan, earning capacity, and so on, the delay will be further aggravated. Setting the levels of compensation is further complicated by the necessity of working backwards from a fixed sum. The Commission still does not possess accurate estimates of the extent of the injuries nor of the needs of the victims. Even more problematically, any estimate of compensation levels will be undermined by the lack of knowledge about the long-term effects of the MIC poisoning. Already, many of the one hundred thousand people who have been classified as only mildly affected by the gas are showing deteriorating symptoms, including tuberculosis and other respiratory complications, gastro-intestinal problems, and deteriorating eyesight. Medical and social activists point out that almost no attention has been paid to the increasing evidence of chromosome damage, immune deficiency, and mental health problems. As the Principal Secretary of the Bhopal Gas Tragedy Commission confirmed, "we really don't know what the future has in store for us." ${ }^{\text {"107 }}$

The Bhopal episode was unique only in the magnitude of its consequences. During the course of the Bhopal litigation itself, dozens of other chemical leaks occurred throughout India resulting in hundreds of injuries. ${ }^{108}$ An International Labour Organization project, undertaken in the wake of the Bhopal tragedy has identified four hundred chemical facilities in India that constitute major industrial hazards. ${ }^{109}$ Hazardous incidents resulting from the leak or misuse of toxic chemicals occur on a frighteningly regular basis in every country, regardless of its state of development. The U.S. E.P.A. discovered a total of 6,928 such incidents between 1980 and 1985 , resulting in an estimated one hundred fifty deaths and fifteen

107 Sathyam, supra, note 104.

108 Indian Post (17 March 1988) reports on a leak of ammonia gas from a chemical plant near Bombay resulting in one hundred injuries. There have been at least four such leaks over the past year in this state alone.

109 Hindustan Times (11 May 1989). 
hundred injuries. ${ }^{110}$ A similar data base in Canada has recorded twenty-three thousand spills in a fifteen year period. ${ }^{111}$

Nor is the failure of information unique to situations involving Third World countries. While chemicals represent about ten per cent of total world trade, ${ }^{112}$ far too little is known about their risks to health and environment. For example, information on health hazards is available on only ten per cent of all pesticides. ${ }^{113}$ This, notwithstanding that there may be as many as one million pesticide poisonings per year in the world. ${ }^{114}$

Nor is the failure of law unique to the Third World. There is little reason to feel complacent about the ability of Canadian regulators to prevent such a disaster, or about the capacity of Canadian law to respond to one. Environmental objectives, standards, and compliance timetables are products of negotiation between government and industry. Regulatory resources are limited and the bargaining power of industry is large. The chemical industry, for example, is the fifth largest industrial sector in Canada, ${ }^{115}$ and is dominated by multinationals. In its brief against

110 This study examined incidents involving both toxic materials and radioactive materials. It was conducted for the U.S. E.P.A. "Acute Hazardous Data Base," Washington D.C.: noted in World Commission on Environment and Development, Our Common Futurc (The Brundtland Report) (United Kingdom: Oxford University Press, 1987) at 228 [hereinafter Brundiland Report].

111 Environmental Protection Service, National Analysis of Trends in Emergencies System, reported in Bhopal Aftermath Review Steering Committee, Bhopal Aftermath Review: An Assessment of the Canadian Situation (Ottawa: Environment Canada, 1986) (Chair: D.W. Bissett) at $41-42$.

112 Brundtland Report, supra, note 110 at 224.

113 Ibid. at 224.

114 See D. Weir \& M. Shapiro, Circle of Poison: Pesticides and People in a Hungry World (San Francisco: Institute for Food and Development Policy, 1981); Hazarika, supra, note 1 at 18 citing World Health, August-September 1984; C.S. Pearson, Down to Busincss: Multinational Corporations, The Environment and Development (Washington D.C.: World Resources Institute, 1985) at 2 citing United Nations Economic and Social Commission for Asia and the Pacific, Committee on Industry, Technology, Human Settlements and the Environment, Seventh Session, 6-12 September 1983.

115 Bhopal Aftermath Review, supra, note 111 at 35. 
greater access to information, the Canadian Chemical Producers' Association threatened:

It is a fact that if unnecessary or excessive costs, delays or uncertainty are introduced unilaterally by any country, (or province), innovation and development will simply cease or be transferred to jurisdictions with a more favourable business climate. Should this happen in Canada, it could be very quickly reduced to a warehouse economy for chemicals. 116

Numerous Canadian studies have confirmed that governmental agencies rely heavily upon industry for information and self-monitoring, that enforcement is sporadic, and that the minimal fines for environmental offences are treated as a cost of doing business. ${ }^{117}$ For example, a recent study of waste management in British Columbia found that "a substantial number of firms habitually violate environmental and occupational health and safety regulations" and that they are virtually immune from punishment. ${ }^{118}$ And while public and private compensation systems in this country may be more adequate than in India, they are far from perfect. Class actions are highly restricted, ${ }^{119}$ proof of negligence is difficult, traditional theories of causation may bar recovery for "statistical injuries," ${ }^{120}$ and the high cost of litigation remains a significant barrier to fair compensation.

At a minimum, the lessons of Bhopal require that attention be focused on the allocation of responsibilities among the various

116 Canadian Chemical Producers' Association, Position Paper on Confidentiality, quoted in T.F. Schrecker, Political Economy of Environmental Hazards (Ottawa: Law Reform Commission of Canada, 1984) at 69.

117 See generally Schrecker, ibid.

118 R. Brown \& M. Rankin, "Persuasion, Penalties, and Prosecution: Administrative v. Criminal Sanctions" in M.L. Friedland, ed, Securing Compliance: Seven Case Studies (Toronto: University of Toronto Press, 1990) at 325.

119 Naken v. General Motors of Canada Ltd (1983), 144 D.L.R. (3d) 385 (S.C.C.).

120 See Probabilistic Causation, supra, note 9. The tendency to reverse the onus of proof of medical causation in difficult cases, begun in the case McGhee v. National Coal Board, [1973] 1 W.L.R. 1, has been rejected by the Supreme Court of Canada in Farrell v. Snell (August 1990) Doc. No. 20873 though the court indicated that in appropriate cases a plaintiff need not establish proof of causation to a scientific standard. 
actors in hazardous industrial sectors. Especially in the case of joint ventures, technology transfers, and multinational undertakings, responsibility can too easily fall through the links in complex chains of command. In addition to Bhopal and Chernobyl, the problems of acid rain and atmospheric warming are increasingly revealing the global consequences of hazardous industries. As both an importer and exporter of hazardous technologies, Canada has an interest in participating vigorously in the development of international environmental law.

As the Bhopal saga illustrates, if Canada maintains a fault-based regime, legal processes must be devised that more effectively maximize available compensation funds and reduce administrative costs; that relieve individuals of the burden of litigation; and that consolidate claims while maintaining due regard for the individual interests and concerns of the victims. This challenge may be especially important in view of the limited availability of the class action in this country. One immediately realizable goal is the development of a scheme of interim financial assistance for all victims of disasters, large and small. ${ }^{121}$ Similarly, existing guarantees of financial responsibility, minimum capitalization and mandatory insurance requirements should be re-examined. The commitment to an "all-purpose" corporate veil must be constantly tested against the requirements of public safety and environmental quality. ${ }^{122}$ The notions of absolute responsibility for industrial hazards and enterprise liability deserve serious consideration as means for partially removing the burden of litigation from the victims of environmental disasters. Ultimately, however, the failings of the Bhopal Act and subsequent litigation teach the necessity of going further towards developing a model of public responsibility ${ }^{123}$ which separates the process of compensation from that of litigation. This could be achieved by strengthening public welfare schemes, and,

121 See, for example, the proposed Rules of Court, B.C. on "Interim Payment of Damages, Debt or Other Sum Including Costs."

122 A glimmer of hope along these lines is the decision in Berger v. Willowdale A.M.C. (1983), 41 O.R. (2d) 89, 145 D.L.R. (3d) 247 (Ont. C.A.).

123 See Gaskins, supra, note 9. 
perhaps, by developing superfund models of compensation and litigation. These models would entitle the victims of industrial and environmental hazards to at least a minimum of compensation from a public fund. ${ }^{24}$ The fund would, in turn, be financed by risk premiums from industry or through subrogated rights of action. ${ }^{125}$

The Bhopal story is replete with ironies and contradictions. The sovereign state of India, proud of its hard won independence from colonial rule, resorts to the courts of a foreign nation to obtain justice for its citizens. A major multinational corporation, whose policy is to maintain "centralized integrated corporate strategic planning, direction and control"126 argues that it had no responsibility for its subsidiary. And the courts of a country that is "among the foremost exporters of effective liberal legal ideologies for the ex-colonial nations of the Third World," the American legal system is incapable of even assuming jurisdiction over an American-based corporation, much less providing a remedy to the victims of the disaster.

In the end, the Bhopal story is one of incredible human suffering as yet unredeemed by significant positive responses from the political, legal, and business communities. The law proved itself entirely unable to prevent the disaster, and as yet unable to repair

\footnotetext{
124 Ontario has begun this process by enacting its "Spills Bill," supra, note 20. For a discussion of superfund approaches to compensation see P.J. Strand, "The Inapplicability of Traditional Tort Analysis to Environmental Risks: The Example of Toxic Waste Pollution Victim Compensation" (1983) 35 Stan. L. Rev. 575. On such a model, the victims of industrial and environmental accidents would be entitled to compensation from a public fund, financed by risk premiums from industry. The fund would, in turn, be responsible for any subsequent litigation. To solve the complex causation problems, the victims might have to establish only "probabilistic" causation and their compensation could be reviewed on a periodic basis rather than received in a lump sum. On the idea of probabilistic causation and proportional recovery, see Public Law Vision, supra, note 9.
}

125 One such model is discussed in J. Gressner, "The 1973 Japanese Law for the Compensation of Pollution-Related Health Damage: An Introductory Assessment" (1975) 8 Law in Japan 7.

126 Union Carbide Corporate Charter, in Union of India's Memorandum in Opposition to Union Carbide's Motion to Dismiss, reproduced in Baxi \& Paul, supra, note 4 at 62 [emphasis omitted].

127 Ibid at iii. 
or alleviate the human distress and agony once it had occurred. Bhopal is, as the Indian Supreme Court said, a test of the promises of law. And for the time being, it cannot be said that those promises have been kept. 